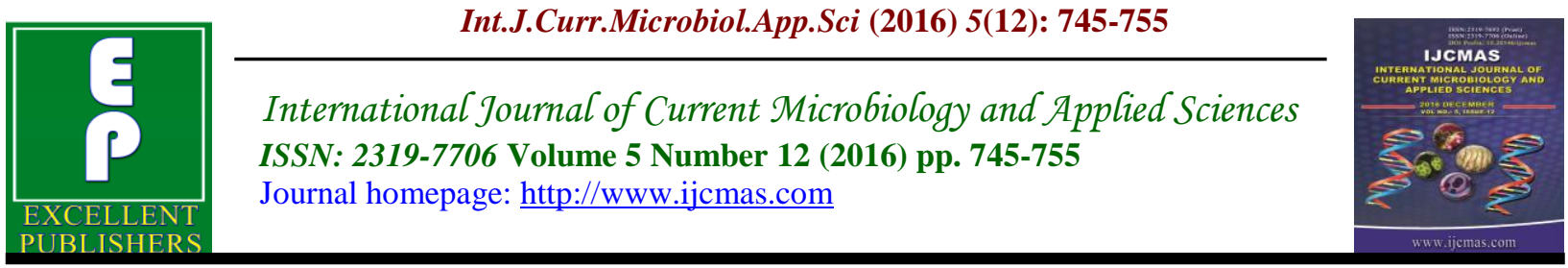

Original Research Article

http://dx.doi.org/10.20546/ijcmas.2016.512.085

\title{
Natural Growth and Vertical Distribution of Marine Red Alga Grateloupia filicina (Rhodophyta/ Gigartinales) and its Associated Fauna
}

\author{
D. Babitha* and Vasuki Subramanian
}

\author{
CAS in Marine Biology, Faculty of Marine Sciences, Annamalai University, \\ Parangipettai, Tamil Nadu, India \\ *Corresponding author
}

\begin{tabular}{|c|c|}
\hline & A B S T R A C T \\
\hline Keywords & \multirow{4}{*}{$\begin{array}{l}\text { Marine algae living in the intertidal zone must endure changes in temperature, } \\
\text { wave action, salinity and moisture, which become more intense as height increases. } \\
\text { Species diversity declines with height above sea level, as fewer species can tolerate } \\
\text { these increasingly harsh conditions. The vertical distribution of Grateloupia } \\
\text { filicina, and species composition along with associated fauna were examined on } \\
\text { from August } 2013 \text { to July 2014. This study demonstrates a rapid increase in the } \\
\text { growth parameters from January onwards and attaining maximum growth in } \\
\text { April/May. Also a significant negative correlation between the biomass and height } \\
\text { above sea level was observed. There are indications that types of algae particularly } \\
\text { the foliose and the encrusting species generally occupy different areas in the } \\
\text { intertidal zone. The seaweed showed different tolerance response to environmental } \\
\text { parameters and nutrient levels. Maximum numbers of associated fauna (density) } \\
\text { was recorded in the mid tidal zone when compared to low and high inter tidal zone. } \\
\text { The limited number of species and simple community structure may be due to the } \\
\text { pollution and ditophiisturbance of macroalgal habitats by human activities. }\end{array}$} \\
\hline $\begin{array}{l}\text { Grateloupia, } \\
\text { Biomass, } \\
\text { environmental } \\
\text { parameters, } \\
\text { Associated Fauna, } \\
\text { Intertidal, } \\
\text { Ecology, Seasonal } \\
\text { fluctuations. }\end{array}$ & \\
\hline Article Info & \\
\hline $\begin{array}{l}\text { Accepted: } \\
\text { 26 November } 2016 \\
\text { Available Online: } \\
10 \text { December } 2016\end{array}$ & \\
\hline
\end{tabular}

\section{Introduction}

The seaweed distribution on rocky intertidal zone endures a range of physical and biological stresses (Kumar and Reddy, 2012). To determine the pattern of distribution, it is essential to consider the relationship between relevant abiotic variables and cover of seaweed over time. Usually, the seaweeds are distributed as parallel bands along the rocky intertidal zone, where the distribution and abundance along the lower inter tidal zone is mainly controlled by biotic factors such as predation and intra and inter-specific competition
(Graham and Wilcox, 2000), while the distribution in the upper zone is mostly determined by abiotic factors such as UV radiation, light, salinity, temperature, nutrient availability and air exposure (Lobban and Harrison, 2001).

Temperature disrupts the metabolic processes, such as respiration and photosynthesis and in turn it greatly affects seaweed abundance (Lobban and Harrison, 1994; Ladah et al., 1999). Intense wave action may detach seaweeds from 
substratum (Denny, 1995; Gaylord, 2000). Seawater salinity causes osmotic and ionic stresses (Kirst, 1989). Bleaching of fronds in seaweed is associated with strong desiccation and irradiance (Scrosati and DeWreede, 1998). The presence of certain algal grazers might cause variations in biomass and limit their distribution on rocky shore (Tanio, 2010; Castro and Huber, 2008).

There is apparently no published studies on the population dynamics for seaweed from the Pondicherry coast and research on the physiological response of seaweeds to abiotic conditions is lacking. Grateloupia filicina along with other seaweed species is found to be growing in the rocky intertidal regions. Due to the existence of carrageenan in its cell walls and to the antiviral and cytotoxic activity reported for tissue extracts (Kim et al., 1997), this species constitutes a potential economic resource. The species of G. filicina are more important as the plants are cultivated as a source of food and carrageenan in many countries (Chandraprabha et al., 2012).

Hence, in the present study vertical distribution of algal in the rocky intertidal zone was carried out. And also along with this physical factors such as temperature (atmospheric and seawater), wave action, chemical factors such as salinity, $\mathrm{pH}$, nutrient and biological factors, presence of grazers was also under taken.

\section{Materials and Methods}

\section{Study site}

The study site was the southern side of Pondicherry coast $\left(48^{\circ} 49 \phi \mathrm{N}, 125^{\circ} 10 \phi \mathrm{W}\right)$, located near sangalikuppam village. This area receives the direct impact of the large waves from the open ocean. Seaweeds were found to occur in the high intertidal zone, about 3-4 $\mathrm{m}$ above the lowest normal tide (based on Chart Datum). At the study site, Grateloupia filicinais a codominant alga together with Chaetomorpha antennaeand Centroceros, whereas it is the only dominant perennial alga in the high intertidal zone of the high wave-exposure site.

The distribution of seaweed was studied in an area of $500 \mathrm{~m}^{2}$ from lower intertidal levels to high intertidal regions. To study the vertical distribution lower intertidal regions (Spot 1), mid-shore regions (Spot 2) and high intertidal regions (Spot 3) was fixed. This study was carried out for 12 months during August 2013 to July 2014. On each sampling date, all the algal material were collected occurring in three $100-\mathrm{cm}^{2}$ quadrats (Baardseth, 1970) taken randomly from the Spot 1, 2 and 3 located across the bed. The collected material was taken to the laboratory in plastic bags inside a cooler. In the laboratory, thalli were cleaned from other benthic materials (sand, pieces of sea shell and worm tubes), blotted dry, and weighed.

Grateloupia filicina occurs as spatially separated clumps (thalli) composed each of a variable number of fronds arising from a small holdfast. It is difficult to count the number of individual plants per quadrant so single fronds arising from holdfast was assumed as single plant and for that length was measured. Mean and standard error for length and fresh weight of individual fronds, biomass (fresh weight), percentage cover and number of plants per quadrate were determined. The atmospheric temperature was recorded every month. Other abiotic factors such as seawater temperature, salinity, $\mathrm{pH}$, dissolved oxygen, nitrate, nitrite, ammonia, total nitrate, inorganic phosphate, total phosphate and silicate of the seawater collected at the study site, were 
determined. The correlation coefficient ' $\mathrm{r}$ ' and significant level between various parameters were calculated. The distribution of associated seaweeds and fauna was also recorded during the study period.

\section{Results and Discussion}

Though there are six species of Grateloupia reported from different parts of the Indian coast (Sahoo et al., 2001; Baweja and Sahoo, 2002), a detailed study on its distribution and natural growth of this species is not available.

\section{Monthly growth behavior}

The monthly variation in length of the frond showed similar pattern (Fig.1.). The maximum length of $20.7 \pm 0.1,17.8 \pm 0.1$ and $15.1 \pm 0.3 \mathrm{~cm}$ were observed during February 2014 at low, mid and high intertidal zone respectively. The density of plants per quadrate was highest in May 2015 at the entire intertidal zone (Fig. 2).

The maximum value for percentage cover $78.04 \%$ for low intertidal zone during May 2015 and $61.0 \%$ and $47.22 \%$ for middle and high zone during April 2015 were recorded (Fig. 3). Similarly, maximum value for the biomass $415 \pm 0.1,292 \pm 0.2$ and $190 \pm 0.1 \mathrm{~g}$ fresh weight were recorded during May 2015 respectively at low, middle and high intertidal zone (Fig. 4). All the growth parameters showed similar trend but the values recorded for low intertidal zone was higher compared to others. There was significant correlation between the biomass and height i.e. low inter zone $(\mathrm{r}=-$ 0.294; $\mathrm{P}<0.5$ ) Table. 1.

Seasonal studies on marine algae along the Indian shores were studied by several authors. Untawale et .al (1989) described the distribution of intertidal algae of northern Karnataka coast and reported 65 species with maximum biomass during December and February months. Similarly Oza et al., (1991) studied the growth and phenology of Gracilaria verrucosa and observed peak growth period during January /February months, whereas in the present study a rapid increase in the growth parameters was observed from January onwards and they attain maximum growth in April/May.

The length of individual plants showed negative correlation with low $(\mathrm{r}=-0.126)$ and mid $(\mathrm{r}=-0.256)$ intertidal region whereas positive correlation was observed with high intertidal region $(\mathrm{r}=0.437)$. However, these values are found to be nonsignificant. The fresh weight of individual plants showed negative correlation with low $(\mathrm{r}=-0.025 ; \mathrm{P}<0.5)$ and $\mathrm{mid}(\mathrm{r}=-0.635)$ whereas positive correlation was observed with high intertidal region $(\mathrm{r}=0.364 ; \mathrm{P}<0.5)$ (Table.1).

Unlike, the biomass reported for Grateloupia filicina $0.6,0.4$ and $0.3 \mathrm{~g} / \mathrm{m}^{2}$ for March-June, July-Oct and Nov.-Feb from Bhimili Coast of Visakhapatnam (Rao et al., 2011) higher values were recorded in the present study $\left(415 \pm 0.1 \mathrm{~g} / \mathrm{m}^{2}\right)$. Rao et al., 2015 reported Grateloupia filicina as dominant seaweed species along with others at Bheemunipatnam, Visakhapatnam. Generally in the mid tidal zone, a lot of tidal pools and crevices cause higher biomass of seaweeds. In the present study the low intertidal zone showed higher biomass compared to other zones.

\section{Environmental parameters}

The correlation coefficient (r) value recorded for various parameters in Grateloupia is given in Table. 1. During the study period, the atmospheric temperature $\left({ }^{\circ} \mathrm{C}\right)$ varied from 29 to 38 and surface temperature from 24 to 29 . There was significant correlation between the biomass 
and atmospheric temperature for mid intertidal zone $(\mathrm{r}=-0.746 ; \mathrm{P}<0.1)$ and high intertidal zone $(\mathrm{r}=0.805 ; \mathrm{P}<0.05$; Surface temperature, $\mathrm{r}=0.804 ; \mathrm{P}<0.05)$. The nitrite $\left(\mathrm{NO}_{2}\right)$, nitrate $\left(\mathrm{NO}_{3}\right)$ ammonia $\left(\mathrm{NH}_{4}\right)$ and total nitrogen varied from 0.057 to 2.890 , 0.456 to $9.056,0.093$ to 2.009 and 1.996 to 12.823, respectively. Likewise, biomass showed significant correlation with nitrate and nitrite for mid intertidal zone $(\mathrm{r}=-0.718$, $\mathrm{P}<01 ; \mathrm{r}=-0.760, \mathrm{P}<0.05)$ and high intertidal zone $(\mathrm{r}=0.702, \mathrm{P}<01 ; \mathrm{r}=0803, \mathrm{P}<0.05)$. The biomass of plants showed a significant positive correlation $(\mathrm{r}=0.830 ; \mathrm{P}=<0.5)$ with ammonia in the low intertidal region. The inorganic phosphate and total inorganic phosphate varied from 0.197 to 2752 and 0.734 to 4.353 respectively. Likewise there was significant correlation between the biomass and inorganic phosphate for low intertidal zone $(\mathrm{r}=0.660 ; \mathrm{P}<0.1)$ and mid intertidal zone $(\mathrm{r}=0.726 ; \mathrm{P}<0.1$, Total phosphate, $\mathrm{r}=0.786 ; \mathrm{P}<0.05)$. The silicate values recorded for the study period varied from 4.302 to 17.337. Comparatively, biomass against silicate in the mid intertidal region also showed significant values $(r=$ 0.935; $\mathrm{P}<0.01)$.

Seaweed species richness shows the conditions of coastal marine ecosystems because it responses sensitively to environmental changes (Murray and Littler, 1984; Prathep, 2005; Choi et al., 2008; Wells et al., 2007). Algal distributions show a significant correlation with some aspects of their submersion/emersion histories, indicating that these events are important in influencing the vertical distribution of intertidal seaweeds (Druehl and Green, 1982). The relationship between chemical compositions of Grateloupia doryphora and Gymnogongrus griffithsiae (turner) martius, and abiotic parameters were studied by Perfeto, (1998). The density of each species of seaweed studied, was showing a correlation of some kind with one or more of the environmental factors monitored. It clearly shows that each species of seaweed requires a specific combination of environmental factors for its biomass production.

Flores-Molina et al., (2014) revealed a different tolerance response of seaweeds, to desiccation i.e. higher intertidal distributions exhibiting better antioxidant enzymatic activity, signifying a higher capability to buffer ROS excess induced during desiccation. This ability appears to be absent or deficient in low intertidal species, where ascorbate peroxidase and catalase activities were below detection limits.

\section{Associated seaweeds and fauna}

Chaetomorpha antennia, Ulva fasciata, Centroceros clavulatum and were found to be associated with Grateloupia. Chaetomorpha antennia occurred as a codominant species. Earlier studies explored in the Persian Gulf (Sohrabipour and Rabei, 1999; Gharanjik, 2011; Rohani Ghadikolaei, 2007) disclose higher assortment of brown algae and in some regions even more than green algae. However in the present study no brown seaweeds were identified. Mostly species of brown algae are very sensitive to environmental changes, type of substratum, and slope. The absence in harsh environments, as reported earlier could be due to the stressors such as disturbance or pollution (Orfanidis et al., 2003; Fatemi et al., 2012). The nutrients such as phosphorus and nitrogen are vital for the growth and development of seaweeds like green algae. Therefore, the existence of abundant green algae might be attributed to that shore (Debore et al., 1978).The green ephemeral algae of both sheet and filamentous forms are generally stress-tolerant species with high reproductive capability in polluted 
areas (Vásquez and Guerra, 1996; Schramm, 1999; Choi et al., 2008). In the present study Chaetomorpha antenninawas found to be present throughout the months. The associated faunal density depends on the morphology of the algae (structure, texture, colour and contour) and its sediment retaining capacities. Many species inhabiting marine algae depend on them for food and shelter. The most common browsers are polychaetes, amphipods and gastropods. Many are filter feeders, detritus feeders, scavengers or carnivores; algivores ranging from minute crustaceans to large sized gastropods (Sarma, 1974). A clear zonation of algae and associated peracarids in a vertical gradient was described by Guerra-García et al., (2010).

Except few studies (Ashwinikumar et al., 2014) the faunal association with seaweeds along Indian coasts are meager (Sarma 1974). Here, in the present study, maximum numbers of animals were recorded in the mid tidal zone (range $=8$ to10) when compared to low and high inter tidal zone (range $=5$ to10). The maximum no of Chiton followed by Thias, Perna indica and Cellana radiata were found to be associated with seaweeds. Littorina spp. (periwinkles) are well adapted physiologically to live at the top of the shore. These are found to be close associated with the seaweed on which it feeds. Barnacles are most common on more exposed shores where there is less algal cover.

The present work clearly have demonstrated a trend of increased foliose algae (Ulva fasciata) at lower regions of the intertidal zone, progressively giving way to a mid-zone of encrusting algae Centroceeros and Chaetomorpha antennia to a high inter tidal zone. Grazing gastropods were abundant in the mid intertidal zone.

Table.1 The correlation coefficient (r) value recorded for various parameters in Grateloupia

\begin{tabular}{|l|l|l|l|l|}
\hline Sl.no & Parameters & Low & Mid & High \\
\hline 1. & Biomass vs Intertidal region & -0.294 & -0.868 & -0.389 \\
\hline 2. & Biomass vs dissolved oxygen & -0.562 & 0.133 & -0.097 \\
\hline 3. & Biomass vs atmtemp & -0.212 & -0.746 & 0.805 \\
\hline 4. & Biomass vs surtemp & -0.197 & -0.356 & 0.804 \\
\hline 5. & Biomass vs salinity & -0.469 & -767 & 0.395 \\
\hline 6. & Biomass vs pH & -0.279 & -0.701 & 0.451 \\
\hline 7. & Biomass vs $\mathrm{No}_{2}$ & -0.525 & -0.718 & 0.702 \\
\hline 8. & Biomass vs $\mathrm{No}_{3}$ & -0.467 & 0.760 & 0.803 \\
\hline 9. & Biomass vs $\mathrm{NH}_{4}$ & $0.830 \mathrm{p}=<0.5$ & 0.391 & -0.136 \\
\hline 10. & Biomass vs total nitrogen & -0.838 & -0.266 & 0.346 \\
\hline 11. & Biomass vs inorganic $\mathrm{PO}_{4}$ & 0.660 & 0.726 & -0.016 \\
\hline 12. & Biomass vs total $\mathrm{PO}_{4}$ & 0.523 & 0.786 & -0.053 \\
\hline 13. & Biomass vs SiO & 0.163 & $0.935 \mathrm{p}=<0.5$ & -0.178 \\
\hline 14. & Individual length vs intertidal $\mathrm{R}$ & -0.126 & -0.256 & 0.437 \\
\hline 15. & Individual fresh.$w t$ vs intertidal & $-0.025 \mathrm{p}=<0.5$ & -0.635 & $0.364 \mathrm{p}=<0.5$ \\
& $\mathrm{R}$ & & & \\
\hline
\end{tabular}


Table.2

\begin{tabular}{|c|c|c|c|c|c|c|c|c|c|c|c|c|c|c|c|c|c|c|c|c|c|c|c|c|c|c|c|c|c|c|c|c|c|c|c|c|c|}
\hline \multirow[t]{2}{*}{ Sl.no } & \multirow{2}{*}{$\begin{array}{l}\text { Name of associated } \\
\text { animal }\end{array}$} & \multicolumn{3}{|c|}{ Aug 14} & \multicolumn{3}{|c|}{ Sep 14} & \multicolumn{3}{|c|}{ Oct 14} & \multicolumn{3}{|c|}{ Nov 14} & \multicolumn{3}{|c|}{ Dec 14} & \multicolumn{3}{|c|}{ Jan 14} & \multicolumn{3}{|c|}{ Feb 14} & \multicolumn{3}{|c|}{ Mar 14} & \multicolumn{3}{|c|}{ Apr 14} & \multicolumn{3}{|c|}{ May 14} & \multicolumn{3}{|c|}{ Jun 14} & \multicolumn{3}{|c|}{ Jul 14} \\
\hline & & $\mathrm{L}$ & $\mathrm{M}$ & $\mathrm{H}$ & $\mathrm{L}$ & $\mathrm{M}$ & $\mathrm{H}$ & $\mathrm{L}$ & $\mathrm{M}$ & $\mathrm{H}$ & $\mathrm{L}$ & $\mathrm{M}$ & $\mathrm{H}$ & $\mathrm{L}$ & $\mathrm{M}$ & $\mathrm{H}$ & $\mathrm{L}$ & $\mathrm{M}$ & $\mathrm{H}$ & $\mathrm{L}$ & $\mathrm{M}$ & $\mathrm{H}$ & $\mathrm{L}$ & $\mathrm{M}$ & $\mathrm{H}$ & $\mathrm{L}$ & $\mathrm{M}$ & $\mathrm{H}$ & $\mathrm{L}$ & $\mathrm{M}$ & $\mathrm{H}$ & $\mathrm{L}$ & $\mathrm{M}$ & $\mathrm{H}$ & $\mathrm{L}$ & $\mathrm{M}$ & $\mathrm{H}$ \\
\hline 1. & Cellana radiata & + & + & + & - & + & + & + & + & + & - & + & + & - & + & + & - & - & + & - & + & + & - & + & + & - & + & + & - & + & + & - & + & + & - & + & + \\
\hline 2. & Perna indica & + & + & - & + & + & - & + & + & - & + & + & - & + & + & + & - & + & - & + & + & - & + & + & - & - & - & + & + & - & - & - & + & - & + & + & - \\
\hline 3. & Turbo bruneus & - & + & + & - & + & + & - & + & + & + & + & + & + & + & + & + & + & - & + & + & - & - & + & + & - & + & + & + & + & - & + & + & - & - & + & - \\
\hline 4. & Nassarius stollatus & + & + & - & + & + & - & + & + & - & - & + & - & + & + & - & + & + & + & + & + & - & - & + & + & - & - & + & + & + & - & + & + & - & + & + & + \\
\hline 5. & Thais bufo & + & - & - & + & + & + & - & + & - & + & - & + & + & - & - & + & + & + & + & + & + & - & + & - & - & + & + & + & + & - & + & + & + & + & + & + \\
\hline 6. & Perna viridis & + & + & - & + & + & - & - & + & - & + & - & - & - & + & - & - & + & - & + & + & - & + & + & - & - & + & - & + & - & - & + & + & - & + & + & + \\
\hline 7. & Modiolus metcalfi & - & + & - & + & + & - & - & + & - & + & - & + & - & + & - & - & - & + & + & - & - & + & - & - & + & + & - & + & + & - & - & - & + & - & + & + \\
\hline 8. & Acmaea sp. & - & + & + & - & - & + & - & - & + & - & + & + & + & + & + & - & - & + & - & - & + & - & - & + & - & - & + & - & + & + & - & - & + & - & - & + \\
\hline 9. & neris & + & + & - & - & + & - & + & + & - & + & + & - & + & + & - & + & + & - & + & + & - & + & + & - & + & + & - & + & + & - & + & - & - & + & - & - \\
\hline 10. & Isopods & + & - & - & + & + & - & + & + & - & + & + & - & + & + & - & + & + & - & + & + & - & + & + & - & + & - & - & + & + & - & + & - & - & + & + & - \\
\hline 11. & Amphipods & + & - & - & + & + & - & + & + & - & + & + & - & + & + & - & + & + & - & + & + & - & + & - & + & + & + & - & + & - & - & + & - & - & + & + & - \\
\hline 12. & chiton & + & + & + & - & + & + & - & + & + & - & + & + & + & + & + & - & + & + & - & + & + & + & + & + & + & + & - & + & + & + & + & + & + & + & + & + \\
\hline 13. & Barnacles & - & + & + & - & + & + & - & - & + & - & - & + & - & - & + & - & - & + & - & - & + & - & - & + & - & + & + & - & - & + & - & + & + & - & + & + \\
\hline
\end{tabular}


Monthly variations in the length of G. filicina

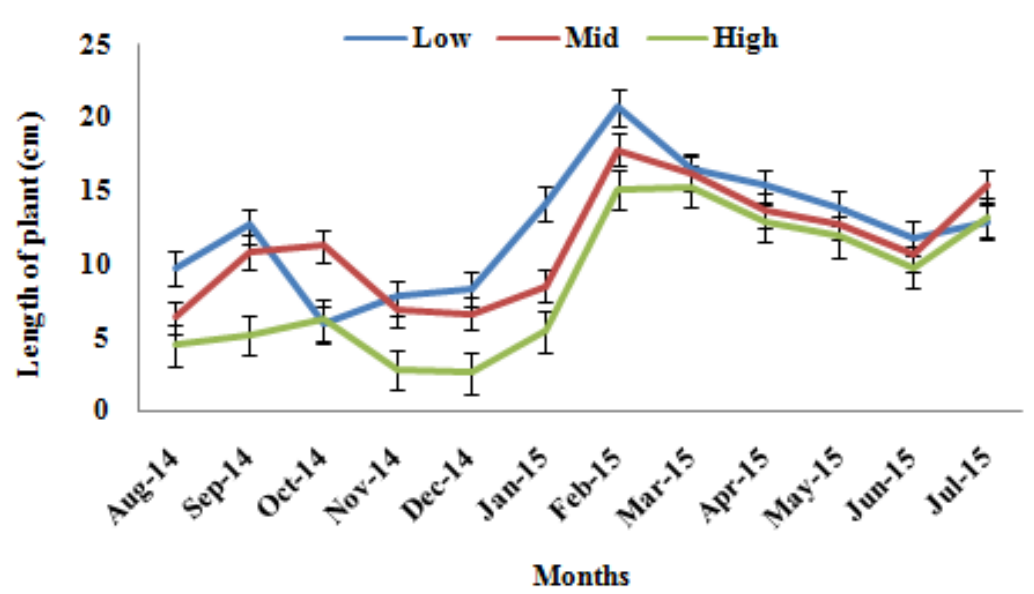

Fig.1 Monthly variations in the length of Grateloupia lithophila

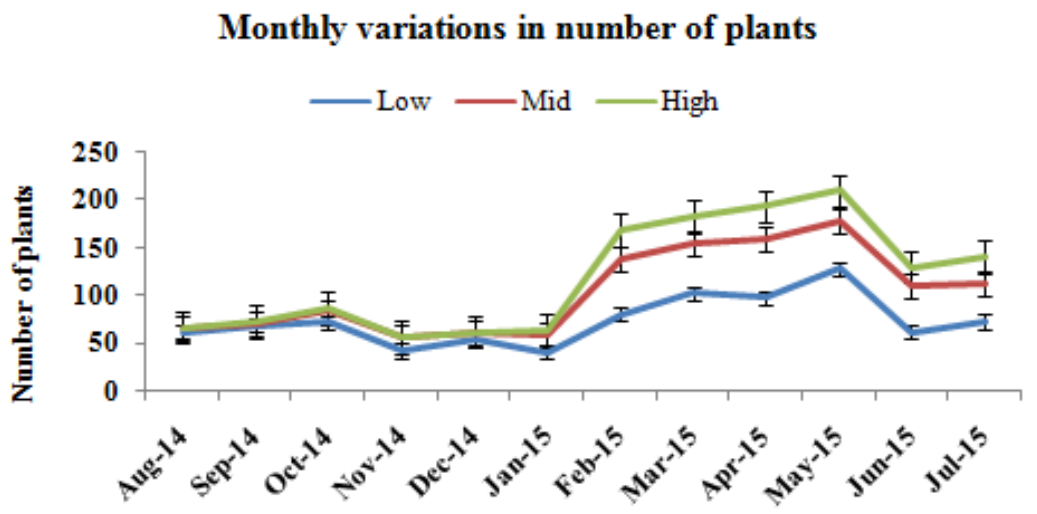

Months

Fig.2 Monthly variations in number of plants (density)

\section{Monthly variation in percentage of Grateloupia filicina}

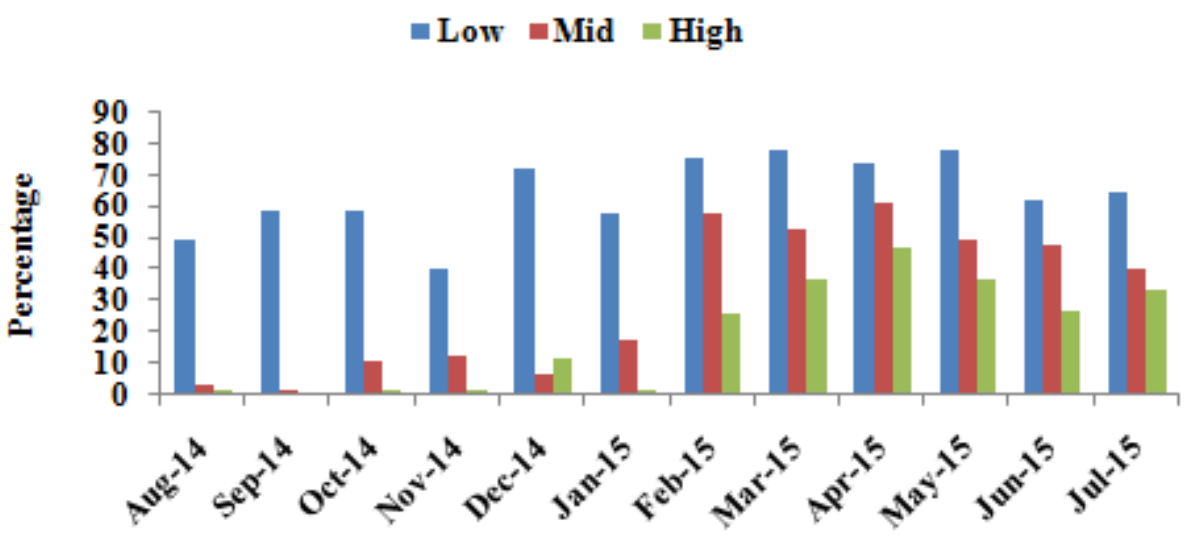

Months

Fig.3 Monthly variations in percentage of Grateloupia lithophila 


\section{Monthly variations in biomass (fr.wt) of Grateloupia filicina \\ Low $\square$ Mid $\quad$ High}

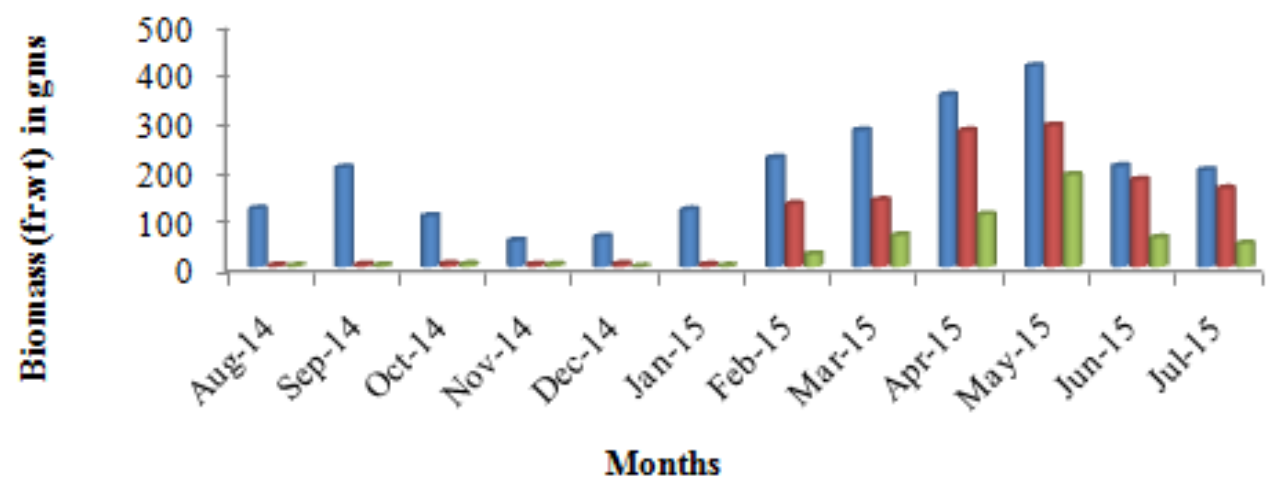

Fig.4 Monthly variations in biomass (fr.wt) of Grateloupia lithophila

This pattern was found to be similar to that found in the New South Wales coastline (Underwood,) but unlike Kioloa's rock pools (Underwood and Skilleter,) where grazing gastropods were absent. The grazing gastropods which can inhibit the growth of macro algal areTurbo spp, Nassarius spp and Thais spp etc.

In conclusion, the organisms in an intertidal zone are exposed to fluctuating degrees of exposure, depending on their height in the zone. The present work shows abiotic factors associated with an intertidal position limits the vertical distribution of marine plants. The limited number of species and simple community structure may be due to the pollution and disturbance of macroalgal habitats by human activities. Since seaweed biomass is a common indicator of the health of marine ecosystems (Piazzi et al., 2002; Arévalo et al., 2007; Ballesteros et al., 2007; Heo et al., 2011) more sampling and analysis would be needed to conclusively establish these patterns.

\section{Acknowledgements}

We are thankful to authorities of Annamalai University for providing the necessary lab facilities to do this work.
Also thankful to Ministry of Human Resource Development (MHRD), Govt. of India for financial support to carry out this work.

\section{References}

Arevalo, R., Pinedo, S. and Ballesteros, E. 2007. Changes in the composition and structure of Mediterranean rocky-shore communities following a gradient of nutrient enrichment: descriptive study and test of proposed methods to assess water quality regarding macroalgae. Mar. Pollut. Bull., 55, 104-113.

Ashwinikumar, P., Soundarapandian, K., Jagan, P., Anatharaman, D., Kannan, Sanjeev kumar, P. Thirunavukkarasu and Arun kumar. 2014. Associated fauna in cultured Seaweed Kappaphycus Alvarezii of Vellar Estuary (South East Coast Of India). Int. J. Res. Mar. Sci., 3(2), 37-43.

Baardseth, E. 1970. Synopsis of biological data on knobbed wrack Ascophyllum nodosum (Linnaeus) Le Jollis. FAO Fish. Synopses No. 38 Rev. 1

Ballesteros, E., Torras, X., Pinedo, S., Garcı'a, M., Mangialajo, L., Torres, M., 2007. A new methodology based 
on littoral community cartography dominated by macroalgae for the implementation of the European water framework directive. Marine Pollut. Bull., 55, 172-180.

Baweja P. and Sahoo, D. 2002. Structure and reproduction of Grateloupia filicina (Halymineniaceae, Rhodophyta) from Indian coast. Algae, 17: 161-170.

Castro, P., Hubber, M.E. 2008. Marine biology. 7th . Ed. McGraw-Hill. 460 p.

Chandraprabha, M., Seenivasan, R. and Indu, H. 2012. RETRACTED: Biochemical and Nanotechnological Studies in Selected Seaweeds of Chennai Coast. J. Appl. Pharmaceutical Sci., 2(11), p.1.

Choi, H.G., Lee, K.H., Yoo, H.I., Kang, P.J., Kim, Y.S,. Nam, K.W. 2008. Physiological differences in the growth of Sargassum horneri between the germling and adult stages. J. Appl. Phycol., 20: 729735.

Choi, H.G., Lee, K.H., Wan, X.Q., Yoo, H.I., Park, H.H., Kim, J.H. and Chung, I.K. 2008. Temporal variations in seaweed biomass in Korean coasts: Woejodo and Jusamdo, Jeonbuk. Algae, 23, 335342.

DeBoer, J.A., Guigli, H.J., Israel, T.L., and D'Elia, C.F., 1978. Nutritional Studies of Two Red Algae. I. Growth Rate as a Function of Nitrogen Source and Concentration. J. Phycol. 14: 261-266.

Denny, M. 1995. Predicting physical disturbance: mechanistic approaches to the study of survivorship on wave-swept shores. Ecol. Monogr., 65: 371-418.

Druehl, L.D. and J.M. Green. 1982. Vertical distribution of intertidal seaweeds as related to patterns of submersion and emersion. Marine Ecology Progress Series, 163-170.

Fatemi, S.M.R., Ghavam Mostafavi, P.,
Rafiee, F. and Saeed Taheri, M. 2012. The study of seaweed biomass from intertidal rocky shores of Qeshm Island, Persian Gulf. Int. J. Mar. Sci. Eng., 2(1), 101-106.

Flores-Molina, M.R., D. Thomas, C. Lovazzano, A. Núñez, J. Zapata, M. Kumar \& L. Contreras-Porcia. 2014. Desiccation stress in intertidal seaweeds: Effects on morphology, antioxidant responses and photosynthetic performance. Aquatic Bot., 113: 90-99.

Gaylord, B. 2000. Biological implications of surf-zone flow complexity. Limnol. Oceanogr., 45: 174-188.

Gharanjik, B. M., Rohani Ghadikolaei, K. 2011. Atlas of the sea algae of Persian Gulf and Oman sea coasts. Iranian Fisheries Research Institute. 1st. Ed. Iranian Fisheries Research Organization. 170p.

Graham, L.E., Wilcox, L.W. 2000. Algae. Upper Saddle River, NJ: Prentice Hall.

Guerra-García, J.M., Sánchez, J.A., Ros, M., Baeza-Rojano, E., Cabezas, M.P., Corzo, J. 2010. Macrofauna asociada al alga Stypocaulon scoparium en el Estrecho de Gibraltar y comparación con el resto de la Península Ibérica. Almoraima

Heo, J.S., Park, K.S., Yoo, H., Song, J.N., Kim, B.Y. and Choi, H.G. 2011. Macroalgal Community Structure on the Rocky Shores of Ongdo, Jusamdo, and Woejodo Islands of the Yellow Sea, Korea. Fish. Aquat. Sci., 14(4), 389-397.

Kim, J.H., Hudson, J.B., Huang, A.M., Bannister, K., Jin, H., Choi, T.J., Towers, G.H.N., Hong, Y.K., DeWreede, R.E. 1997. Biological activities of seaweed extracts from British Columbia, Canada, and Korea. I. Antiviral activity. Can. J. Bot., 75: 1656-1660.

Kirst, G.O. 1989. Salinity tolerance of eukaryotic marine algae. Annu. Rev. Plant Physiol. Plant mol. Biol., 40: 
$21-53$.

Kumar, M., Reddy, C.R.K., 2012. Oxidative Stress Tolerance Mechanisms in Marine Macroalgae (Seaweeds): Oxidative Stress in Seaweeds. LAP Lambert Academic Publishing, Germany.

Ladah, L.B., Zertuche-Gonzalez, .JA., Hernandez-Carmona, G. 1999. Giant kelp (Macrocystis pyrifera, Phaeophyceae) recruitment near its southern limit in Baja California after mass disappearance during ENSO 1997-1998. J. Phycol., 35: 1106-12

Lobban, C.S., Harrison, P.J. 1994. Light and photosynthesis. In: Lobban CS, Harrison PJ (eds) Seaweed ecology and physiology. Cambridge University Press, Cambridge, pp 123-162.

Lobban, C.S. \& Harrison, P.J. 2001. Nutrient physiology of seaweeds: Application of concepts to aquaculture. Cah. Biol. Mar., 42: 7182.

Murray, S.N., Littler, M.M., 1984. Analysis of seaweed communities in a disturbed rocky intertidal environment near Whites Point, Los Angeles, Calif., USA. Hydrobiologia, 116/117, 374-382.

Orfanidis, S., Panayotidis, P., Stamatis, N. 2003. An insight to the ecological evaluation index (EEI). Ecol. indicator, 3, 27-33.

Oza, R.M., Tewari, A. and Rajyaguru, M.R. 1991. Growth and Phenology of Red alga Gracilaria verrucosa (Huds.) Papenf. Indian J. Mar. Sci., Vol. 18, No.2, pp. 82-86

Perfeto, P.N.M., 1998. Relation between chemical composition of Grateloupia doryphora (Montagne) Howe, Gymnogongrus griffithsiae (Turner) Martius, and abiotic parameters. Acta Botanica Brasilica, 12(1), pp.77-88.

Piazzi, L., Pardi, G., Balata, D., Cecchi, E. and Cinelli. F. 2002. Seasonal dynamics of a subtidal north-western Mediterranean macroalgal community in relation to depth and substrate inclination. Bot. Mar., 45, 243-252.

Prathep, A. 2005. Spatial and temporal variations in diversity and percentage cover of macroalgae at Sirinat Marine National Park, Phuket province, Thailand. Science Asia, 31: 225-233.

Rohani Ghadikolaei, K., Rajabi, I., Rameshi, H., Dehghani, R., Behzadi, S., Hosseini, M.R., Tamadoni, S. 2007. A study on distribution and biomass estimination of seaweeds in coastal and its islands. Fisheries, 15(4), 59-68.

Sarma, A.L.N. 1974. The Phytal fauna of Sargassum off Visakhapatnam coast" J. Marine Biol. Association of India, 16(3): 741-755.

Satya Rao, K., Prayaga Murty, P. and Narasimha Rao, G.M., 2011. Seasonal studies on marine algae of the Bhimili coast, east coast of India. J. Algal Biomass Utilization, 2(2), pp.69-82.

Schramm, W. 1999. Factors influencing seaweed responses to eutrophication: some results from EU-project EUMAC. J. Appl. Phycol., 11, 6978.

Scrosati, R., DeWreede, R.E. 1998. The impact of frond crowding on frond bleaching in the clonal intertidal alga Mazzaella cornucopiae (Rhodophyta, Gigartinaceae) from British Columbia, Canada. $J$. Phycol., 34: 228-232.

Sahoo, D., Nivedita and Debasish, 2001. Seaweeds of Indian Coast. APH Publishing Corporation, New Delhi. $283 \mathrm{pp}$.

Sohrabipour, J. \& Rabii, R. 1999. A list of marine algae of sea shores of the Persian Gulf and Oman sea in the Hormozgan province. Iran. J. Bot., 8(1): 131-162.

Taino, S. 2010. Different effects on 
seaweed succession after sea urchin removal at several coastal waters in Tosa Bay, southern Japan. Bull. Fish. Res. Agen., 32, 61-67.

Untawale, A.G., Reddy, C.R.K. and Deshmukhe, G.V. 1989. Ecology of Intertidal Benthic Algae of Northern Karnataka Coast. Indian J. Mar. Sci., Vol.18, No.2, pp.73- 81

Vasquez JA and Guerra N. 1996. The use of seaweeds as bioindicators of natural and anthropogenic contaminants in northern Chile. Hydrobiologia, 326/327, 327-333.

Wells, E., Wilkinson, M., Wood, P.,
Scanlan, C., 2007. The use of macroalgal species richness and composition on intertidal rocky seashores in the assessment of ecological quality under the European Water Framework Directive. Mar. Pollut. Bull., 55, 151-161.

Yedukondala Rao, P., Rukmini Sirisha, I. and Sudha Rani, D. 2015. Distribution of seaweeds along the coastal waters of Visakhapatnam, East Coast of India. Int. J. Acd. Res., Vol.3, No.5, pp. 2320-5083.

\section{How to cite this article:}

Babitha, D., and Vasuki Subramanian. 2016. Natural Growth and Vertical Distribution of Marine Red Alga Grateloupia filicina (Rhodophyta/ Gigartinales) and its Associated Fauna. Int.J.Curr.Microbiol.App.Sci. 5(12): 745-755.

doi: http://dx.doi.org/10.20546/ijcmas.2016.512.085 